\title{
Taxonomic relevance of seed and seedling morphology in two Amazonian species of Entada (Leguminosae)
}

\author{
Rodrigo Schütz RODRIGUES ${ }^{*}$, Gildo Vieira FEITOZA² and Andréia Silva FLORES ${ }^{2}$ \\ ${ }^{1}$ Universidade Federal de Roraima, Centro de Estudos da Biodiversidade. Av. Ene Garcez, 2413, CEP: 69304-000, Boa Vista, Roraima, Brazil. \\ * Corresponding author: rodschutz@gmail.com. \\ ${ }^{2}$ Instituto de Amparo à Ciência, Tecnologia e Inovação do Estado de Roraima, Museu Integrado de Roraima, Herbário MIRR. Av. Brigadeiro Eduardo Gomes, 1128, \\ CEP: 69330-640, Boa Vista, Roraima, Brazil.gdfeitoza@gmail.com, andreiasflores@gmail.com.
}

\section{ABSTRACT}

We carried out a comparative morphological study to evaluate the taxonomic value of seed and seedling traits of Entada polystachya and E. simplicata (Leguminosae, Mimosoideae, Mimoseae). Seeds of both species were collected from wild populations in Roraima State, Brazil. Our results show consistent quantitative and qualitative differences between these species regarding their seeds and seedlings. Testa fracture lines, funiculus impression, lens characters, radicle shape and length, and cotyledon lobes length, seedling morphology group, number of pinnae at first node, and hypocotyl length permit a straightforward distinction of $E$. polystachya from E. simplicata, supporting a recent treatment of the latter taxon as a distinct species, endemic to Roraima State, northern Amazonia, Brazil.

KEYWORDS: Fabaceae, Mimosoideae, embryo, post-seminal development, testa

\section{Relevância taxonômica da morfologia de sementes e plântulas em duas espécies amazônicas de Entada (Leguminosae)}

\section{RESUMO}

Este trabalho apresenta um estudo morfológico comparativo para avaliar o valor taxonômico de caracteres de semente e plântula de Entada polystachya e E. simplicata (Leguminosae, Mimosoideae, Mimoseae). As sementes de ambas as espécies foram coletadas de populaçóes no Estado de Roraima, Brasil. Os resultados evidenciaram consistentes diferenças qualitativas e quantitativas entre estas espécies, com relação as suas sementes e plântulas. Linhas de fratura na testa, impressão do funículo, caracteres da lente, forma e comprimento da radícula e comprimento dos lobos dos cotilédones, grupo morfológico de plântula, número de pinas no primeiro nó eofilar e comprimento do hipocótilo permitem uma separaçáo entre E. polystachya e E. simplicata, providenciando apoio a um recente reconhecimento do último táxon como uma espécie distinta, endêmica no Estado de Roraima, Norte da Amazônia, Brasil.

PALAVRAS-CHAVE: Desenvolvimento pós-seminal, embrião, Fabaceae, Mimosoideae, testa 


\section{INTRODUCTION}

Entada Adans. (Leguminosae, Mimosoideae) is a pantropical genus comprising ca. 28 species (Luckow 2005). In Brazilian Amazonia, all taxa of Entada belong to E. sect. Entadopsis (Britton) Brenan, because they have leaves generally lacking foliar tendrils, chartaceous and craspedial fruits, and small (up to $20 \mathrm{~mm}$ in diam.) and pleurogrammatic seeds (Brenan 1966; Rodrigues and Flores 2012).

In Roraima State (Northern Brazilian Amazonia), only two species of Entada have been recorded (Rodrigues and Flores 2012), E. polystachya (L.) DC., and E. simplicata (Barneby) Sch. Rodr. \& A.S. Flores. While E. polystachya has a wider distribution, occurring from Western Mexico to tropical South America (Barneby 1996; Barneby 2001), E. simplicata is endemic to Roraima State. The taxonomic history of the latter taxa initiated with Barneby (1996), who described E. polystachya var. simplicata based on a single flowering collection. However, despite the uniformity of their floral characters, as already pointed out by Barneby (1996), E. simplicata has been recently recognized as a distinct species from E. polystachya on the basis of leaf and fruit characters (Rodrigues and Flores 2012).

In Leguminosae, seed and seedling morphology studies have provided characters with taxonomic relevance (e.g. Gunn 1981; 1984; Gurgel et al. 2012). Entada exhibits a particularly great variation in seed characters (Gunn 1984), which have been used to recognize sections and subsections (Brenan 1966). Indeed, in several instances they also permit identification to species level (Brenan 1966; Tateishi et al. 2008). On the other hand, although there are few data concerning seedling morphology of Entada, some studies have demonstrated that seedling morphology is helpful for species-level identifications in some African and New World Entada (Lungu and Culham 1996; Garwood 2009).

For E. polystachya, seed and seedling morphology are known only from illustrations (Gunn 1984; Garwood 2009) and brief information mostly in floristic papers (Barneby 2001; Forero and Romero 2009; Garwood 2009). Nevertheless, to our knowledge, no previous study concerning seed and seedling morphology of E. simplicata has been carried out, as their fruits have been only recently described (Rodrigues and Flores 2012). This paper describes and illustrates the seed and seedling morphology of Entada polystachya and E. simplicata, in order to evaluate their taxonomic value in distinguishing both species.

\section{MATERIALS AND METHODS}

Seeds of Entada polystachya (L.) DC. and E. simplicata (Barneby) Sch. Rodr. \& A.S. Flores were obtained from wild populations in Roraima State. Seeds from five E. polystachya populations and one E. simplicata population were collected, whose vouchers are housed at the Herbarium of the Museu Integrado de Roraima (MIRR): Entada polystachya: Flores et al. 2002, Flores \& Peixoto 2137, Flores et al. 2469, Rodrigues et al. 1846, Rodrigues et al. 2129; Entada simplicata: Flores \& Peixoto 2147. One hundred seeds were measured for each species. Additionally, available herbarium seeds of E. polystachya at MIRR were analyzed: Lewis 1432, Milliken et al. 168.

Character surveys covered quantitative and qualitative traits. Photographs were taken with a Nikon D90 camera, the testa details with a stereoscope with a camera attached (SMZ-51, Nikon, Tokyo, Japan), and drawings of embryos were done using a stereoscope with a camera lucida attachment (SMZ-800, Nikon, Tokyo, Japan). Measurements were taken using Mytutoyo calipers. Descriptive terminology of seeds follows Gunn (1981; 1984) and Kirkbride et al. (2003), except for the relative pleurogram elevation, and the relative lens and radicle lobe length. In preparing the material for dissection, mature seeds were hydrated in boiling water for $30 \mathrm{~s}$ to $90 \mathrm{~s}$, depending on testa resistance.

For seedling morphology study, seeds were mechanically scarified and germinated on wet filter paper in petri dishes. For each taxon, seeds were sown under the same light (sun and shade) and temperature in greenhouse conditions at MIRR. After the emergence of the primary root, the seedlings were moved to plastic tubs with humus and sand mix (1:1). Qualitative and quantitative data were recorded for each taxon until the complete development of the third eophyll following Rodrigues and Tozzi (2008). Descriptions were based primarily on records of living specimens and also on a combination of dry and alcohol preserved material, following the terminology of Garwood (2009). Altogether 30 seedlings of E. simplicata and 40 seedlings of $E$. polystachya were analyzed, whose vouchers were deposited at the Herbarium of the Museu Integrado de Roraima (MIRR): E. simplicata: Rodrigues \& Feitoza 2177 and 2179; E. polystachya: Rodrigues \& Feitoza 2178 and 2180.

\section{RESULTS}

\section{Common traits in seed and seedling of studied species}

Seeds of Entada polystachya and E. simplicata were oblong to elliptic, flattened, symmetrical (Figure 1A-F), and in a single transverse non-overlapping series. The testa of both species was dark brown, chartaceous. Both taxa were pleurogrammatic, having a $90-100 \%$ pleurogram (Figures $1 \mathrm{G}, \mathrm{L}, \mathrm{N}$ ). The hilum was punctiform, apical, and both aril and endosperm were absent. Cotyledons were oblong to elliptic, with a lobed base and a rounded apex. Groined cotyledon lobes were found in both taxa (Figures 2A, D-E), but in E. simplicata not touching 


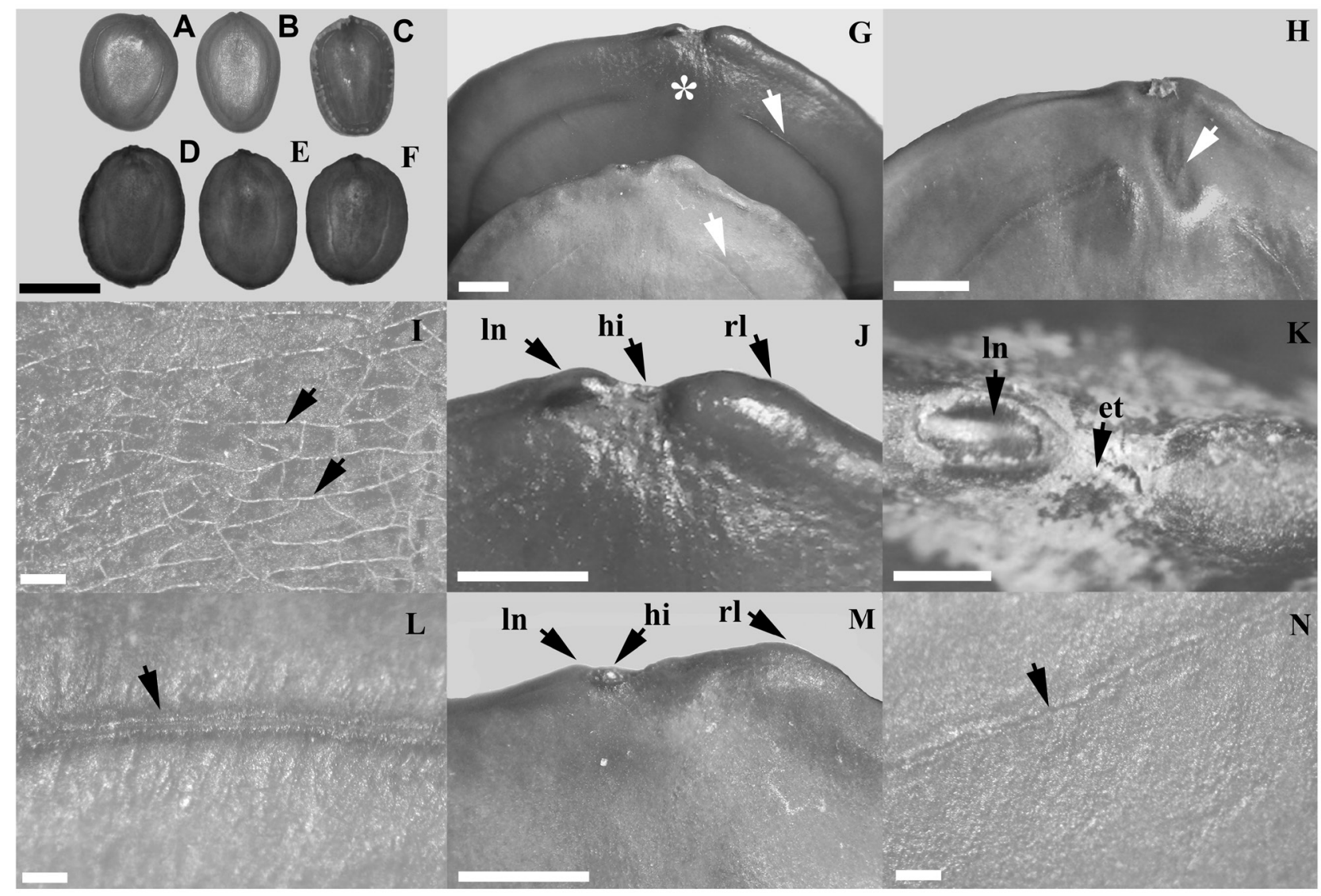

Figure 1. Seeds of Entada polystachya (L.) DC. and E. simplicata (Barneby) Sch. Rodr. \& A.S. Flores (Leguminosae, Mimosoideae). A-C. Seeds of E. polystachya. D-F. Seeds of E. simplicata. G. Detail of the apical region of the seed in E. simplicata (at the bottom) and E. polystachya (at the top, with an asterisk), arrow showing the pleurogram. H. Funiculus impression (arrow) on the testa in $E$. simplicata. I. Detail of the testa of $E$. polystachya, showing fracture lines (arrows). J. Detail of the hilum region of $E$. polystachya, showing the lens (In) equaling the radicle lobe (rl) in height, and the hilum (hi). K. Detail of the lens (In) of $E$. polystachya, which has a dissimilar color from that of the testa, and adnate patches of endocarp tissues (et) on the testa. L. The pleurogram (arrow) in $E$. polystachya. M. Detail of the hilum region of $E$. simplicata, showing the lens (In), which has a similar color to the testa and is conspicuously shorter than the radicle lobe (rl), and the hilum (hi). N. Detail of the testa of $E$. simplicata, showing the pleurogram (arrow), and lacking fracture lines. Bars: $A$ to $F=1 \mathrm{~cm} ; \mathrm{G}$, $\mathrm{H}, \mathrm{J}$ and $\mathrm{M}=1 \mathrm{~mm} ; \mathrm{I}, \mathrm{L}$ and $\mathrm{N}=0.2 \mathrm{~mm} ; \mathrm{K}=0.5 \mathrm{~mm}$.

cotyledon lobes (sensu Kirkbride et al. 2003) also occurred (Figure 2B). The embryonic axis was straight, and the plumule was moderately developed (Figures 2C, F).

Both Entada polystachya and E. simplicata had phanerocotylar seedlings with storage (reserve), sessile, nonnyctinastic cotyledons (Figures 3A, D). Cotyledonary buds were inconspicuous or up to $4 \mathrm{~mm}$ long, which elongated when the axis of the seedling was damaged in a young stage. The hypocotyl and epicotyl were terete, glabrous, and without cataphylls. Axillary buds were generally conspicuous, and stipules were linear-lanceolate (Figure 3A). Leaves were pinnate and opposite (or sub-opposite in E. polystachya) at the first node (Figures $3 \mathrm{~A}, \mathrm{D}$ ), and twice pinnate and alternate at later nodes. Leaflets were oblong to obovate, asymmetrical at the base, and rounded to truncate at the apex, with a brochidodromous venation. In both taxa, leaflets presented a "forward-folding" nyctinastic movement, which involves a forward twisting and an upward movement of each leaflet (Figure 3C).

\section{Description of seeds and seedlings of Entada polystachya}

Seeds $12-17 \mathrm{~mm}$ long, 8-13 wide, $2-4 \mathrm{~mm}$ thick. Testa smooth with adnate white to cream patches of endocarp tissues (Figure $1 \mathrm{~K}$ ); fracture lines conspicuously present (Figure 1I); funicular impression on the testa surface near the seed apex absent. Lens $0.5-0.8 \mathrm{~mm}$ long, with dissimilar color to the testa (Figures $1 \mathrm{~J}-\mathrm{K}$ ), equaling the radicle lobe in height (Figures 1G, J). Cotyledons 11-15.5mm long, 9-10 mm wide, 1.2-1.7 mm thick; cotyledon lobes 2.8-3.8 mm long (Figure 2D-E); radicle 3.7-4.7 $\mathrm{mm}$ long, 2-2.5 $\mathrm{mm}$ wide, bulbose (Figure 2F); plumule 1-1.7 mm long. Seedling morphology group PER (phanerocotylar, epigeal, reserve) (Figure 3D). 

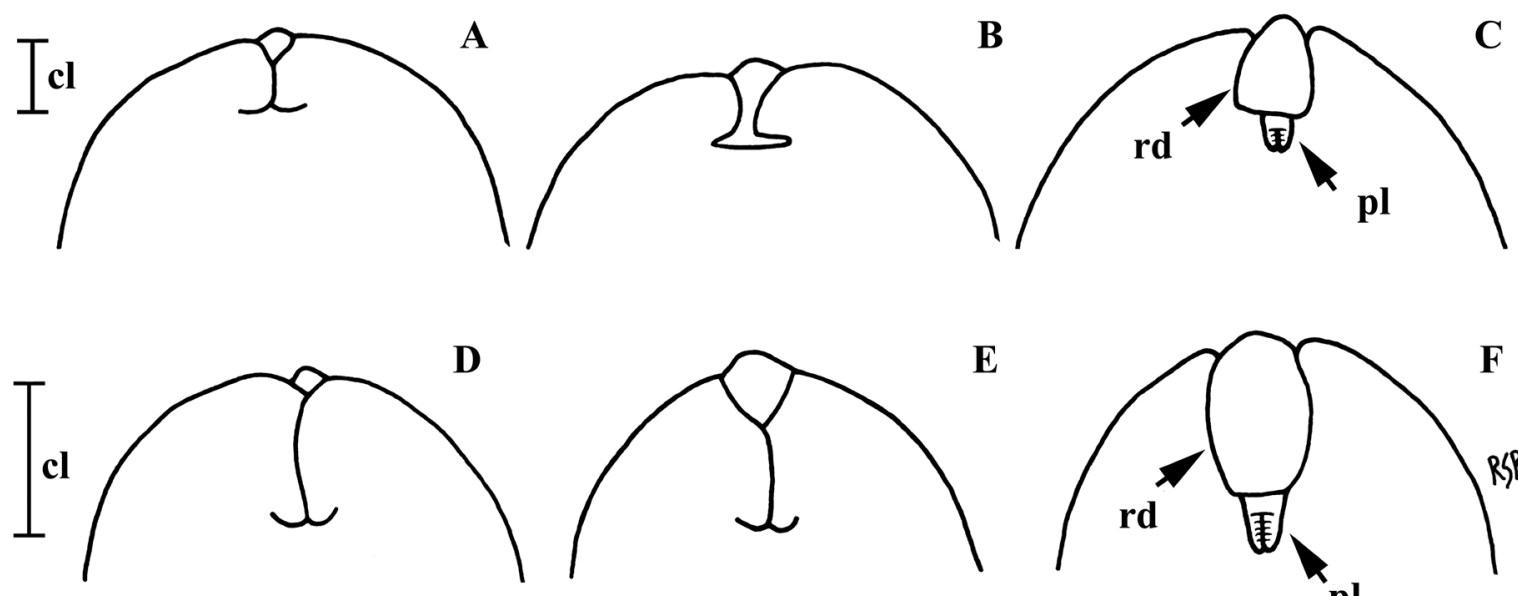

$\mathbf{E}$

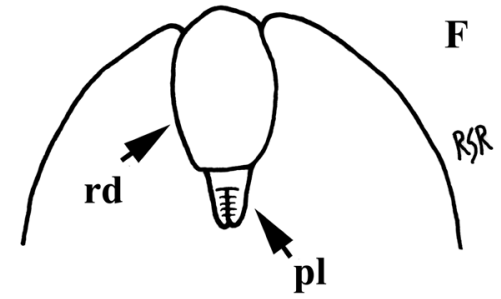

Figure 2. Cotyledon bases of embryos of Entada polystachya (L.) DC. and E. simplicata (Barneby) Sch. Rodr. \& A.S. Flores (Leguminosae, Mimosoideae). A-C. Entada simplicata. A. Groined cotyledon lobes. B. Not touching cotyledon lobes. C. Embryo with radicle (rd) and plumule (pl) exposed. D-F. Entada polystachya. D-E. Groined cotyledon lobes. F. Embryo with radicle (rd) and plumule (pl) exposed. Abbreviations: cl (length of cotyledon lobes). Bar: A to F $=2 \mathrm{~mm}$.

Hypocotyl 21-44 mm long, 2-3 mm wide. Seedling cotyledons 18-23 mm long, 13-15 $\mathrm{mm}$ wide, 2-2.5 mm thick (Figure 3E); seedling cotyledon lobes 5.5-7 mm long. Epicotyl 73$146 \mathrm{~mm}$ long, 1.2-1.5 mm wide. Seedling stipules 0.5-1.5 $\mathrm{mm}$ long. First node eophyll with 7-10 pinnae (Figure 3D); terminal leaflet blade 14-24 mm long, 7-14 mm wide. Second and third node eophylls with 1(-2) pinnae, each pinna with 4-5 pairs of leaflets; terminal leaflet blade 13-27 $\mathrm{mm}$ long, 6-15 $\mathrm{mm}$ wide.

\section{Description of seeds and seedlings of Entada simplicata}

Seeds 14-20 mm long, 9-13 mm wide, 2-4 mm thick. Testa smooth, adnate patches of endocarp tissues absent; fracture lines absent; with funicular impression (>90\% of observed seeds) on the testa surface near the seed apex. Lens $0.3-0.5$ $\mathrm{mm}$ long, with similar color to the testa (Figure $1 \mathrm{M}$ ), shorter than the radicle lobe in height (Figure 1G, M). Cotyledons 13-18 mm long, 9-11 mm wide, 1.3-2 mm thick; cotyledon lobes 1.5-1.8 mm long; radicle 2.4-2.7 mm long, 1.7-2.1 $\mathrm{mm}$ wide, triangular (Figure 2C); plumule 1-1.1 mm long. Seedling morphology group PHR (phanerocotylar, hypogeal, reserve) (Figure 3A). Hypocotyl 2-6 mm long, 2-2.5 mm wide. Seedling cotyledons 19-24 mm long, 13-17 mm wide, 1.5-2.5 $\mathrm{mm}$ thick (Figure 3B); seedling cotyledon lobes $2.5-3.5 \mathrm{~mm}$ long. Epicotyl 49-103 mm long, 1-1.5 mm wide. Seedling stipules $0.5-3 \mathrm{~mm}$ long. First node eophyll with 4-6 pinnae (Figure 3A); terminal leaflet blade 13-32 mm long, 7-19 mm wide. Second and third node eophylls with 1 pinna, each pinna with 2-4 pairs of leaflets; terminal leaflet blade 9-37 $\mathrm{mm}$ long, 5-18 $\mathrm{mm}$ wide.

Table 1 - Summary of diagnostic characters of Entada polystachya and E. simplicata (Leguminosae, Mimosoideae) seeds and seedlings.

\begin{tabular}{lll}
\hline Characters/Taxa & E. polystachya & E. simplicata \\
\hline Testa fracture lines & present & absent \\
Testa funiculus impression & absent & generally present \\
Relative height of lens to radicle & equal to radicle lobe & shorter than the radicle lobe \\
\hline Lens coloration & dissimilar to testa & similar to testa \\
Cotyledon lobes length & $2.8-3.8 \mathrm{~mm}$ & $1.5-1.8 \mathrm{~mm}$ \\
Radicle shape & bulbose & triangular \\
Radicle length & $3.7-4.7 \mathrm{~mm}$ & $2.4-2.7 \mathrm{~mm}$ \\
\hline Seedling morphology group & PER (phanerocotylar, epigeal, reserve) & PHR (phanerocotylar, hypogeal, reserve) \\
\hline Hypocotyl length & $21-44 \mathrm{~mm}$ & $2-6 \mathrm{~mm}$ \\
\hline Seedling cotyledon lobes length & $5.5-7 \mathrm{~mm}$ & $2.5-3.5 \mathrm{~mm}$ \\
\hline First node eophyll: number of pinnae & $7-10$ & $4-6$ \\
\hline
\end{tabular}




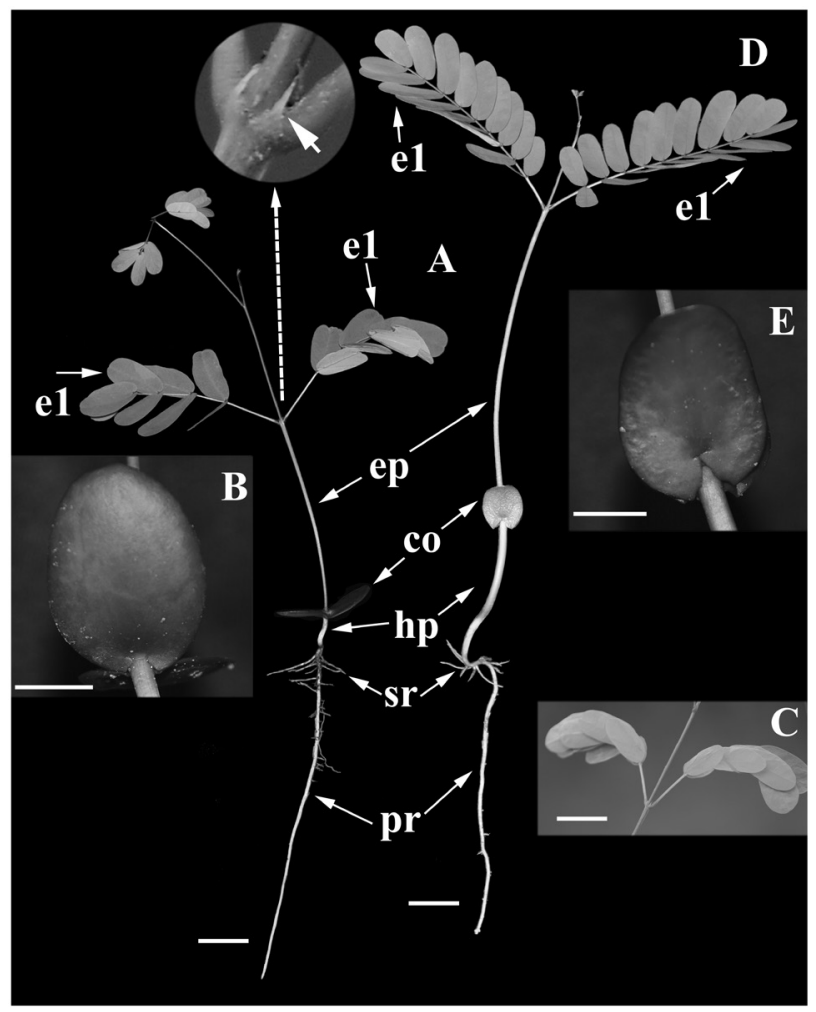

Figure 3. Seedlings of Entada polystachya (L.) DC. and E. simplicata (Barneby) Sch. Rodr. \& A.S. Flores (Leguminosae, Mimosoideae). A-C. Entada simplicata. A. Seedling with fully expanded eophylls at first node, showing in detail the stipules (arrow). B. Detail of a cotyledon (abaxial surface). C. Position of the leaflets at first node eophyll after their forward-folding nyctinastic movement. D-E. Entada polystachya. D. Seedling with fully expanded eophylls at first node. E. Detail of a cotyledon (abaxial surface). Abbreviations: co (cotyledon), e1 (eophylls at first node), ep (epicotyl), hp (hypocotyl), pr (primary root), sr (secondary roots). Bars: $\mathrm{A}, \mathrm{C}$ and $\mathrm{D}=2 \mathrm{~cm} ; \mathrm{B}$ and $\mathrm{E}=1 \mathrm{~cm}$.

\section{DISCUSSION}

This study supports that seed morphology is taxonomic useful in distinguishing the Amazonian Entada polystachya from E. simplicata, as previously observed for some paleotropical Entada species (Brenan 1966; Tateishi et al. 2008). Although seed size clearly overlaps in E. polystachya and E. simplicata, other seed and embryo traits provide most of the idiosyncratic qualitative and quantitative characters found. In fact, expedited low-magnitude observation of seed testa fracture lines, funiculus impression, lens attributes, radicle shape, length of cotyledon lobes, radicle, and plumule on herbarium specimens permits straightforward distinction of E. polystachya from E. simplicata. With respect to seeds, two characters were observed here for the first time in Entada, considering the description provided by Gunn (1984) for the genus: the funiculus impression occurring on the testa surface in E. simplicata, and the groined cotyledon lobes, present in both E. polystachya and E. simplicata.
A comparison between seedlings of populations of Entada polystachya from Barro Colorado, Panama (Garwood 2009) and Roraima, Brazil (this study) shows that both populations have phanerocotylar, epigeal, reserve seedlings. The number of pinnae of the first eophyll (8-9) of the Panamanian population is also within the variation range found in this study for $E$. polystachya. This agreement supports the view that $E$. polystachya possesses seedlings with an equivalent seedling morphology group over a large part of its geographic range. Indeed, the seedling morphology group appears to be a very conservative trait since it is a significant aspect of the reproductive ecology of each particular species (Ibarra-Manríquez et al. 2001). In fact, seedling studies with a taxonomic emphasis in members of some tribes of Leguminosae have not pointed out polymorphic species regarding their seedling group (Rodrigues and Tozzi 2008; Rodrigues et al. 2012).

The seedling morphology group and eophyll characters have allowed identification to species level in both neotropical and paleotropical Entada. Garwood (2009) was able to distinguish seedlings of E. polystachya from E. gigas (L.) Fawc. $\&$ Rendle from Panama on the basis of seedling morphology group, phyllotaxis, and division of the blade (pinnate versus bipinnate) of the first eophyll. Indeed, Lungu and Culham (1996) distinguished three African species of Entada from each other on the basis of differences in their seedling morphology group and the number of pinnae of the first eophyll.

It is taxonomically significant that the seedling morphology group and the number of pinnae of the first node eophyll seedlings distinguish $E$. polystaschya from E. simplicata. Moreover, considering that E. polystachya has phanerocotylar, epigeal, reserve seedlings and E. gigas possesses cryptocotylar, hypogeal, reserve seedlings (Garwood 2009), phanerocotylar, hypogeal, reserve seedlings of E. simplicata are the first reference of this morphology group for Neotropical Entada.

Finally, we have identified several additional qualitative and quantitative differences between seeds and seedlings of $E$. polystachya and E. simplicata, as they are also distinguishable from each other by the number of pairs and width of leaflets, and a suite of fruit characters (Rodrigues and Flores 2012). As a conclusion, our results demonstrate the taxonomic relevance of seed and seedling morphology in Roraima Entada, supporting specific rank for E. simplicata.

\section{ACKNOWLEDGMENTS}

We thank Enrique Forero, Carolina Romero, Yoichi Tateishi, and Tadashi Kajita for kindly sending us literature. Financial support for this work came from Fundação Estadual do Meio Ambiente, Ciência e Tecnologia do Estado de Roraima, FEMACT (proc. 0508/06-1). We thank Emily Clarke for improving the English. We also thank the Conselho Nacional de Desenvolvimento Científico e Tecnológico (CNPq) for scholarship to Andréia Flores. 


\section{REFERENCES}

Barneby, R.C. 1996. Neotropical Fabales at NY: asides and oversights. Brittonia, 48: 174-187.

Barneby, R.C. 2001. Entada Adans. In: Berry, P.E.; Yatskievych, K.; Holst, B.K. (Ed.). Flora of the Venezuelan Guayana. v.6. Missouri Botanical Garden Press, St. Louis, p. 610-611.

Brenan, J.P.M. 1966. Notes on Mimosoideae: XI: The Genus Entada, its subdivisions and a key to the African species. Kew Bulletin, 20: 361-378.

Forero, E.; Romero, C. 2009. Sinopsis de las Leguminosae: Mimosoideae de Colombia. In: Forero, E. (Ed.). Estudios en leguminosas colombianas II. Instituto de Ciencias Naturales, Universidad Nacional de Colombia, Bogotá, p. 9-235.

Garwood, N.C. 2009. Seedlings of Barro Colorado Island and the Neotropics. Comstock Publishing Associates, Ithaca, 645p.

Gunn, C.R. 1981. Seeds of Leguminosae. In: Polhill, R.M.; Raven, P.H. (Ed.). Advances in Legume Systematics, Part 2. Royal Botanic Gardens, Kew, p. 913-925.

Gunn, C.R. 1984. Fruits and seeds of genera in the subfamily Mimosoideae (Fabaceae). United States Department of Agriculture Technical Bulletin, 1681: 1-194.

Gurgel, E.S.C.; Santos, J.U.M.; Lucas, F.C.A.; Bastos, M.N.C. 2012. Morfologia de plântulas de Leguminosae e o potencial sistemático. Rodriguésia, 63: 65-73.

Ibarra-Manríquez, G.; Martinez Ramos, M.; Oyama, K. 2001. Seedling functional types in a lowland rain forest in Mexico. American Journal of Botany, 88: 1801-1812.
Kirkbride, J.H.; Gunn, C.R.; Weitzman, A.L. 2003. Fruits and seeds of genera in the subfamily Faboideae (Fabaceae). United States Department of Agriculture Technical Bulletin, 1890: 1-1208.

Luckow, M. 2005. Mimoseae. In: Lewis, G.; Schrire, B.; Mackinder, B.; Lock, M. (Ed.). Legumes of the World. Royal Botanic Gardens, Kew, p. 163-183.

Lungu, S.; Culham, A. 1996. Seed and seedling morphology of Entada, a study of Zambian species. In: van der Maesen, L.J.G.; van der Burgt, X.M.; van Medenbach de Rooy, J.M. (Ed.). The Biodiversity of African Plants. Kluwer Academic Publishers, Dordrecht, p. 809-814.

Rodrigues, R.S.; Flores, A.S. 2012. A new combination in Entada (Leguminosae) from Roraima, Brazil. Phytotaxa, 39: 47-50.

Rodrigues, R.S.; Hirt, A.P.M.; Flores, A.S. 2012. Morfologia de plântulas das espécies de Rhynchosia (Leguminosae, Papilionoideae) de Roraima, Brasil. Acta Botanica Brasilica, 26: 585-592.

Rodrigues, R.S.; Tozzi, A.M.G.A. 2008. Systematic relevance of seedling morphology in Acosmium, Guianodendron, and Leptolobium (Leguminosae, Papilionoideae). Brittonia, 60: 287-296.

Tateishi, Y.; Wakita, N.; Kajita, T. 2008. Taxonomic revision of the genus Entada (Leguminosae) in the Ryukyu Islands, Japan. Acta Phytotaxonomica et Geobotanica, 59: 194-210.

Recebido em 23/10/2012

Aceito em 19/04/2013 